\title{
Parody: Fake News, Regeneration and Education
}

\section{Christine Sinclair ${ }^{1}$ (D)}

Published online: 20 July 2019

(C) The Author(s) 2019

\begin{abstract}
Understanding forms of imitation and their purposes is an important aspect of postdigital media literacy. Parody is important because it is used not only to generate fake news but also as an antidote to it. For parody to work, it needs to be distinguishable from fake news, and for the author and the audience both to be in on the joke. Using illustrative examples, the paper considers the importance of context, the role of the Bakhtinian notion of double-voiced discourse in understanding parody, and the potential of generating parody as a resource for media literacy education. The concluding section considers parody in relation to the themes of the special issue, using parody relating to Brexit to draw out some final messages, which are disturbing but inconclusive. Parody has a significant shaping presence in our cultures; however, it will not necessarily be easy to harness this for our own ends, even though we should be aware of it.
\end{abstract}

Keywords Imitation · Bakhtin · Laughter - Intertextuality · Double-voiced discourse · Regenring

\section{Introduction: Imitating for a Purpose}

People who want to produce lies, bullshit and fake news need to be able to imitate features of accepted truths and trusted genres. Each imitation may have a different aim; knowing this will be key to understanding and exposing what is happening with these practices. Our world is saturated with imitations for different purposes: we could not function nor learn without imitation (Vygotsky 1978). In order to understand and deal effectively with the themes of this special issue, we must therefore be aware of imitation and its purposes.

In this paper, I argue that we need to pay attention to parody - the allusive imitation of practice that aims to provoke laughter and to expose power and authority for what

Christine Sinclair

Christine.Sinclair@ed.ac.uk

1 Moray House School of Education, University of Edinburgh, Holyrood Road, Edinburgh, UK 
they are and how they operate. Parody and its related forms, such as satire and pastiche, are complicit in fake news, but tend to have different purposes. While fake news sets out to deceive, satire aims to ridicule, and pastiche to re-use for effect motifs from known literary or artistic practices. One writer on parody, Margaret Rose, claims that parody and pastiche are 'devices' that have been around for centuries. The word 'fake' 'adds a value judgement to the use of the device which may or may not be justified' (Rose 1991:37 footnote). We clearly need to be able to distinguish between fakes and other forms of imitation, and the devices they use. However, we should also take care to preserve our ability to allude, critique and even ridicule through parody. Awareness of purpose and intention will be key to our understanding of all of these cultural practices.

Occasionally, a contemporary comedian will complain that the real world is now so bizarre that it is hard to make fun of it through parody and satire. Yet parody is still rife in modern times, just as it has always been but with additional modalities available for its expression and dissemination. There are parodies in art, architecture, drama, music, radio and television, film, blogs and other websites as well as in writing and speech; YouTube in particular is full of parody. Some writers (often influenced by the literary critic, Bakhtin) suggest that parody plays an essential role in our cultures; ironically it helps to counter or moderate essentialising discourses. Evidence from ancient, medieval, modern and postmodern texts indicates that we have always been ready to laugh at authority, institutions, practices - and above all, at ourselves. It is important that we recognize what we have learned, and can continue to learn, through parody.

My aim here is to protect parody from being unfairly tainted and dismissed as lies, bullshit and fake news and to harness its potential for challenging the truly fake. This is not to say that parody is always beneficial, so my task is a complex one. Some parodic intentions may be malign. Parody does not always meet parodic intentions, and can have completely unanticipated consequences. That does not mean that we should ignore it: quite the contrary. The paper contains three sections dealing with the themes of its title. In turn, they consider the context, theoretical perspective and practice of my argument about fake news and parody. Each section contains an illustrative subsection that brings out the potential of parody and its relevance for this special issue. A fourth section reprises key points about parody's relationship with lies, bullshit and fake news, and this time uses parodies of Brexit for illustration. The paper concludes that parody is still an important force in the postdigital era, though there remains some ambivalence about how it can be used.

\section{Parody's Connections to Fake News}

While fake news intends to deceive, parody and satire aim to expose and can even be a necessary weapon in countering fake news (Daniel 2018). In his video, Matt Daniel, editor of the satirical publishing company The Peedmont, claims that 'Fake news is meant to spread lies, but satire can ignite debate' (https:/www.youtube.com/watch?v= YO_n2t2XIqk 1:35). It does this in part through making us aware of our biases and encouraging us to be willing to challenge them. This aim is the opposite of fake news which seeks to exploit those biases to our detriment.

Some writers, though, equate satire and fake news. Tandoc et al. (2018:141) identify news satire as the 'most common operationalization' of fake news in the articles they 
reviewed to create a typology of fake news. Satirists are able to critique their targets through exaggeration and by pointing out inconsistencies in what they are saying. People who watch satirical television news programmes are apparently as knowledgeable about current affairs as people who only watch standard news. Indeed, they would have to be; satire does not work if the viewer does not 'get' the connection. That knowledge might actually emerge through an attempt to understand the satire; Brewer et al. (2013) cite several studies that indicate increased awareness of political campaigns through watching political satire programmes such as The Daily Show in the US.

Tandoc et al. (2018) claim that the only fake aspect of satire is its use of format; the basis of satire is actual events. They contrast this with their second example in their typology of fake news - news parody - suggesting that parodying the news does actually involve making things up. This subtle distinction does show some problems of definition; parody and satire are often used synonymously, though satire is more associated with personal attack (Sinclair 2020). Some would-be satirists would not necessarily exclude fabrication from their practice, as the example at the end of this section will indicate. It is therefore perhaps useful to view satire as a particular manifestation of parody.

A key writer on parody, Dentith (2000) sees parody as just one label for several related forms that inflect human discourse in slightly different ways. It is not always possible to avoid the disputes about definition as some writers will use definition as part of their arguments, and occasionally it can be useful to bring out the subtle distinctions in order to make a point. My own argument here foregrounds the value of educating about parody; to recognize this, it may also be necessary to alert students and teachers to its baser forms.

For my purposes now, though, what is most important in both satire and parody is 'the assumption that both the author and the reader of the news share the gag' (Tandoc et al. 2018:142). This does not always happen; it is well known that the comic online magazine The Onion has sometimes been mistaken for a serious news site. Daniel (2018) also notes that he has failed if his satirical 'fake news' is actually believed. Failed parody - when the audience does not 'get it' - can have problematic consequences. Attempts at parody or satirical attacks may even reinforce the practices or people they are targeting, by drawing further attention to them. They also may miss the mark, especially if the target actually outparodies the satirist through their actions. 'If reality consistently beats you to your punch, you're not writing satire.' (Greenman 2019). If a politician does some of the work of parody anyway, and relishes the attention from the constant reference that parody brings, perhaps a better tactic would be not to mention that person at all, though of course this would forfeit opportunities for laughter and dialogue.

Pundits and scholars are now commenting not only on the news about news, but also on the news about political satire and its effects (Brewer et al. 2013). Brewer et al. believe that it is important to attend to the intertextuality of news and parodies of it to recognize how they work together to shape knowledge, critical opinions and attitudes, enhancing some effects of news items themselves. An aspect of that intertextuality is the expression 'fake news' itself: while fake news has always been around, the expression has not. Now that it has emerged, it 'eliminates the need to engage in any exercises in persuasion or ideological contestation' (Freeden 2018:3). All someone in authority has to do is shout 'fake news' and there is no further discussion. As Freeden 
points out, though, such wordplay does also have a history; over two thousand years ago, Plato reported that the Sophists used the argument that falsehoods had no existence, allowing them to dismiss the idea falsehoods could be a problem.

These points about the differences in intention between fake news and parody, the role of parody in attacking fake news and the value of recognizing, and talking about, the intertextuality of fake news are brought together in the illustrative example that follows.

\section{A Parody of (Fake) News}

On January 16th, 2019, copies of what looked like The Washington Post were handed out in Washington. The paper was dated for the future - May 1st 2019 - and headlined the resignation of the president of the United States. It even had an associated website https://my-washingtonpost.com/. Both the paper and the website were published by a duo known as The Yes Men in an action known as 'culture jamming' - a form of parody that targets mass communications and aims to expose how they operate (Fig. 1).

An article in the online magazine Slate the following day alerted readers to the fact that this stunt was not actually fake news but parody and that it is essential to be able to tell the difference between these (Glaser 2019). April Glaser also argues for the importance of this kind of spoof - and particularly its offline manifestation - in artistically focusing our attention on what we are constantly exposed to on our screens and giving us a reason to pause, reflect and indeed laugh together about a potential future.

Parody that makes us think, laugh and engage in dialogue is far more valuable and important than fake news that deceives. The following section considers a theoretical perspective that provides a framework for understanding how parody achieves this.

\section{Parody's Potential for Dialogue and Regeneration}

A parody entails at least two voices - the speaker and another speaker refracted through the parody. In the example of the Washington Post spoof, the refracted voice of the

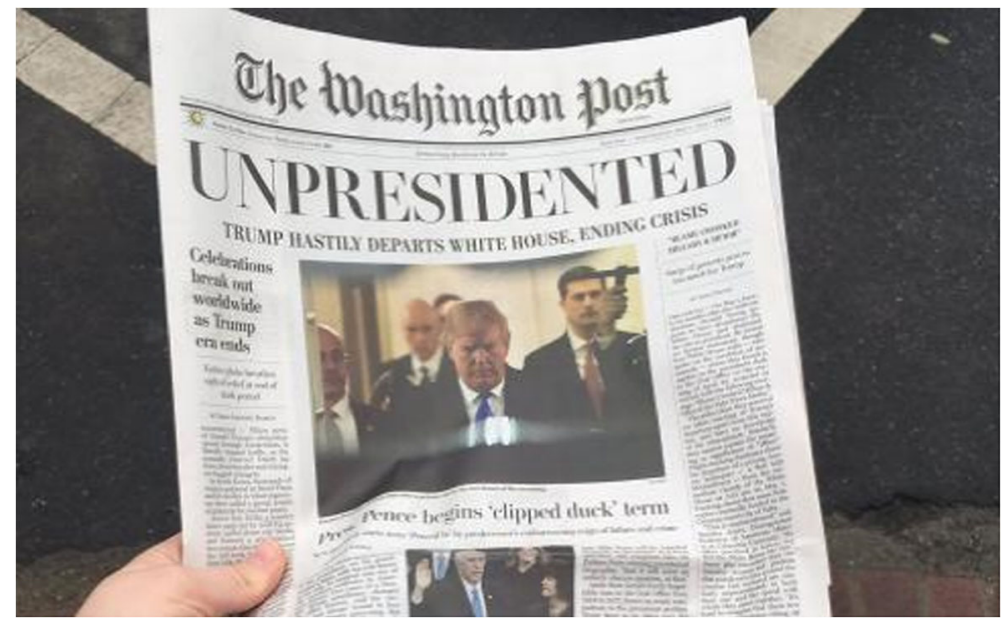

Fig. 1 Copy of the fake edition of The Washington Post. www.theyesmen.org 
newspaper is apparently present; however, the voice of The Yes Men is also making its presence felt through exaggerated (and fabricated) 'news'. The two voices do not share the same values but speak through the same words. The resulting 'double-voiced discourse' is a key construct in Mikhail Bakhtin's work (1895-1975) and an important notion in both postmodern and postdigital studies of contemporary culture. The idea of 'double-voiced' originally emerged in relation to literature and the relationship of the voice of the author to those of the characters in a novel (Bakhtin 1984a). It later became the basis of Bakhtin's extended thinking about human communication. Double-voiced discourse permeates daily speech and writing, as we introduce other people's words into our own and inevitably add our own interpretations and inflexions. We speak through the same words as other people, but extend and alter their meanings in the process.

We do use double-voiced discourse in ways that don't involve parody, of course, including the writing of academic papers where academic authors are fond of weaving dialogues through citations and paraphrases along with their own commentary on them. Less formally, in daily speech we frequently attempt to accommodate our interlocutors' speech as we determine our own contributions to the dialogue. The construct of doublevoiced discourse has also proved useful, for instance, in exploring the role of language in leadership activities and the differences between people's monologic and dialogic approaches (e.g. Baxter 2011).

We can use forms of parody that do not involve double-voiced discourse, such as travesty or what Bakhtin terms 'bare negation' (Bakhtin 1984b). While a person of a tyrannical bent may attempt to mimic a practice they hope to eradicate, the dialogue will not end with them. In fact, the dialogue won't even happen - such a mimicry is monologic. Travesty misrepresents: its imitation is an impoverished one. This means that the original source being imitated is not fully present in the representation and the attack is crude, though it may still have an effect. This kind of negative parody can often be seen in political debates, and any laughter it provokes is more about mockery than insight.

So double-voiced discourse might not be parodic, and parody has forms that are monologic. Other than acknowledging this so that we can be clear about the difference, I am more interested in the dialogic potential of parody, and this was Bakhtin's major contribution not only to literature but also to philosophy and culture. Bakhtin sees literature as a place where 'the carnival spirit' renews itself and this is achieved through parody (Renfrew 2015). The medieval carnival provided its participants with a temporary opportunity to challenge and profane, through parody, the authorities and orthodoxies of its time. Bakhtin's interest in the carnivalesque is explored in his controversial doctoral thesis, written in a time of repression and submitted in 1940, on the work of Francois Rabelais (1483?-1553?). Rabelais' work is sustained by the notion of 'folk humour', with carnival as a place and time where everybody participates and the laughter is directed at all, not only at the powerful and their orthodoxies.

Folk humour denies, but it revives and renews at the same time. Bare negation is completely alien to folk culture.

(Bakhtin 1984b:11)

Looking at literature and culture from previous eras is complex, not least because of canonisation and reaccentuation of texts, which even affect the function and effects of 
parody (Bakhtin 1981). The 'second voice' in double-voiced discourse sometimes disappears through these processes - for example, Cervantes' novel Don Quixote (1605) has gone much further than parodying chivalric romances and has influenced much modern writing. The original works that prompted the parody have long been forgotten. In Discourse in the Novel, originally written in 1934-35, Bakhtin sees this as a positive and significant feature. The 'living word' can never be completely extinguished, but is carried on through new dialogues with new intentions and is the basis for renewal and regeneration.

This is a long way from claiming that we should all use parody to defeat fake news. Indeed, Dentith (2000: 94) advises us not to 'sentimentalize' Bakhtin as parody can be destructive. Dentith also counsels against over strong claims of parody's specific cultural role for a postmodern era. His concern is that we can't actually anticipate the effects of the double voicing and parody: they coexist with so many cultural forces. Dentith does acknowledge the cultural labour that parody does and how it works with other forms to expose connections, interpretations and power relationships.

But the crucial questions remain: what cultural work is the parody effecting? On whose behalf is it working? With what wit and verve is the parody performed? None of these questions can be decided in advance, for all of them require an understanding of particular utterances in particular contexts.

(Dentith 2000: 186)

With so many utterances and so many contexts - and now so many complex interconnections made possible by digital innovation - such understanding will demand a great deal. But the questions are worth asking not only of parody, but also of lies, bullshit and fake news in general.

To underline the dangers of Dentith's warnings about use of Bakhtin's ideas about parody and laughter, it is worth pointing out that some writers are seeing a connection between it and some contemporary anti-establishment figures. The carnival jester who temporarily subverts authority has an appeal that is also seen in some populist leaders (Gaufman 2018; Haworth 2019). I return to this theme later.

While accepting the need to be modest about claims for the work of parody, I do still want to promote the suggestion that dialogic forms of parody keep us talking about writers and their ideas, not only in forms of literature and contemporary media, but also in our daily dialogical interactions. It is perhaps worth exploring the mechanics of double voiced discourse in relation to parody. Parody emerges in a complex mix of interlocutors, context, media, themes, wordplay and previous experience of the audience. The example below shows how this mix can bring together Plato and a contemporary author.

\section{An Original Voice and its Refraction Through Another Author}

Figure 2 shows an annotated example of a parody written in 2006. The writer being parodied is Plato; his dialogue Symposium has been transferred to another medium, an educational site in the now defunct learning management system WebCT, and Plato's theme of love has been changed to the theme of e-learning. The small section shown here is an extract from an initial forum discussion, parodying the introductory section of 


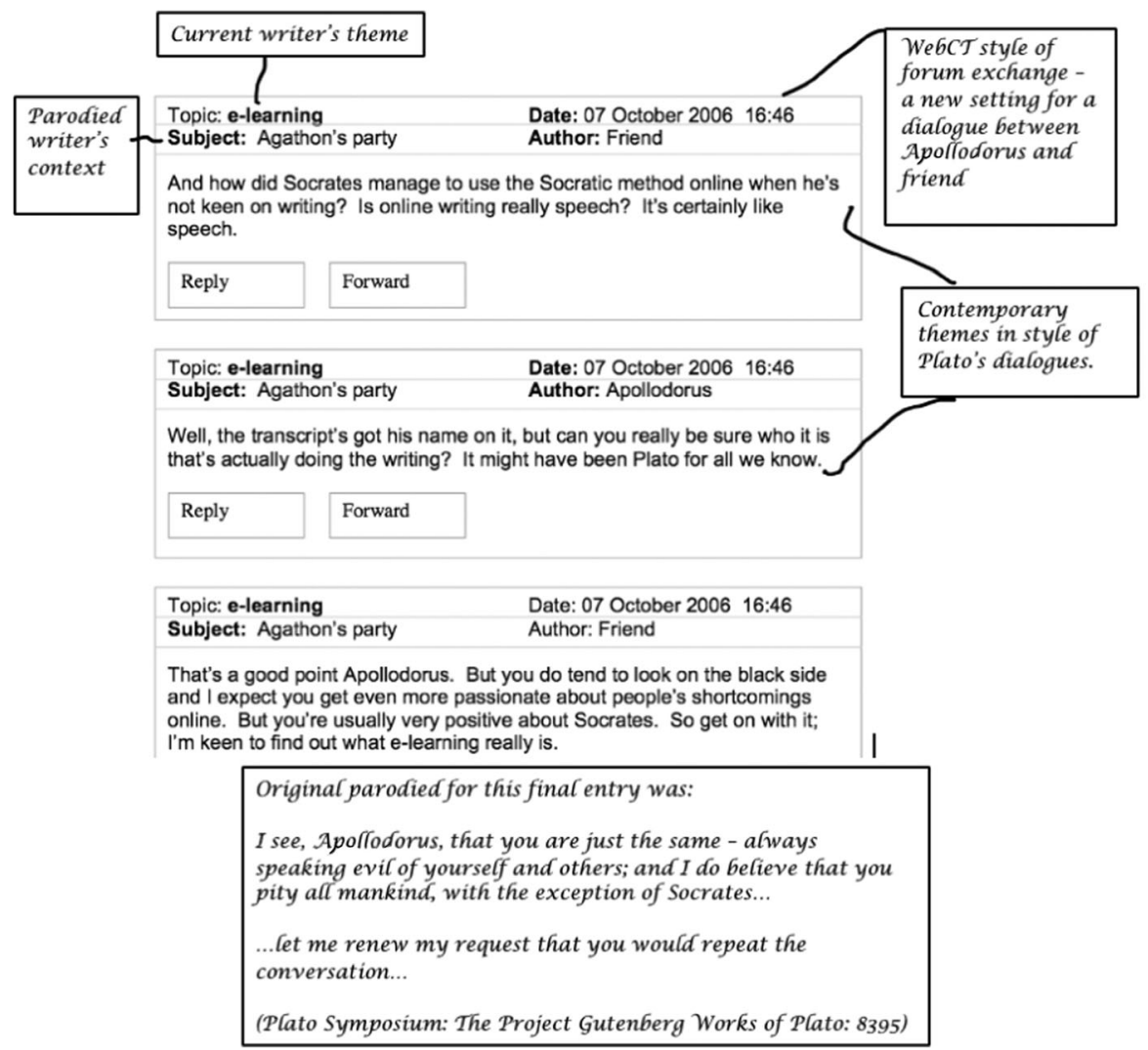

Fig. 2 Annotated parody showing two voices, one (Plato's) refracted through parody

the original book. The parody works on the style - dialogue - using the same characters and including some of their characteristics, both from the original document and also through other known facts (e.g. that Socrates did not write).

The author has used the opportunity to bring out some points about e-learning, such as online writing is like speech, the concern expressed by some people that an online writer (especially a student) might be an impostor, and the suggestion that people can be ruder and more negative online. In the full version from which this was taken, the longer speeches made in the Symposium about the nature of love have been turned into blog posts about the nature of e-learning. Each contains a statement that is exactly the same as one of Plato's protagonists about love, except that the word Love has been replaced by E-Learning. For example, Eryxymachus says:

we must praise the god E-learning, who is our greatest benefactor, both leading us in this life back to our own nature, and giving us high hopes for the future (Plato 2009 release, with my amendment)

The use of parody allowed empty, inflated and ridiculous claims about e-learning to mirror similar claims made about love two millennia earlier. 
The main aim of Fig. 2 is to show the presence of different voices and the intertextuality and double-voiced utterances that accompany them. There are the two protagonists, the writer, Plato, who is known for capturing dialogues involving Socrates, and there is the current author who is writing about e-learning. Plato himself used refracted voices - the dialogue in the Symposium is recounted through Apollodorus telling his companion what he has heard from Aristodemus - none of these people were actually present at the Symposium, casting some doubt on the truthfulness of the account.

The ability to recognize, identify and understand the two (or more) voices in doublevoiced discourse should be available to all. This is then a task for education.

\section{Educating About Parody; Educating Through Parody}

The main purpose of writing this paper is to highlight the educational potential of parody and to consider whether it would help us to discriminate between dialogic parody and monologic fake news. Young people should be capable of working this out for themselves; learning through imitation, mockery and laughter is part of growing up. However, there are counter pressures in education where imitation is limited to drill and practice towards getting the right answer, without questioning what is behind it. By setting students the task of parodying what is to be studied, a teacher can assist in the refraction of the original voice through finding out what that voice said. In exploiting the double-voiced nature of parody, such an activity can stimulate learning about both the target of the parody and another practice that speaks through the parody. It also teaches about parody itself.

I was the author of the parody in the previous section when I was a part-time student on the University of Edinburgh's MSc in E-learning (now known as the MSc in Digital Education). My parody, written in 2006 for my first assignment, took me a long time longer than writing a standard essay would have. However, I had several purposes in doing it: I wanted to exploit the then unusual opportunity offered by this innovative programme to be creative and multimodal in an assignment. I also needed to learn about creating a WebCT site for my full-time job at another university. (I was initially undertaking the programme in order to find out what it was like to be an online student; I soon discovered that I wanted to take the programme because I was learning so much.) Having previously been a student of philosophy, I was familiar with the Symposium. I wanted to parody it with a view to finding resonance with e-learning and also to explore whether it would possible to 'transfer' teaching of an ancient text to a learning management system (LMS). Through parodying it, I learned so much more about the nuances of the Symposium as well as the continuities and disjunctions between our time and Plato's. At the same time, I also learned about the affordances and barriers offered in an LMS, and how the statuses of student and teacher were affected by these. Perhaps most importantly for the purposes of the assignment, I was able to display what I had learned during my first semester about e-learning and its debates through tying them into my parody.

Later, as a teacher on the same programme, I encouraged my own students to use parody themselves. I use this as an example at the end of the section; first, though, I want to say a little more about my reasons for doing so. I had for a long time been interested in students' difficulties with academic writing. I had empathy with these 
difficulties having experienced them myself at times, and earlier in my career found I could support undergraduate students to identify and imitate 'the peculiar ways...' (Bartholomae 1985) of academic writing.

In researching academic literacies and experimenting with ways to support imitation without veering into formulaic writing or plagiarism, I came across the work of Fiona English (2011). She has developed an approach she calls 'regenring', which uses the idea of genre as a social semiotic resource rather than a goal (English 2011: 4 and 76). Through her experiences of working with students to change the genre of one of their existing academic essays - for example, into a newspaper article, story, play, debate... - English demonstrates that regenring can have lasting pedagogic effects on students' relationships with their academic discipline. The results of her writing experiment astonished both English and her students, offering profound insights into student engagement and the nature of academic genres through the contrast with others. This includes critique: genre is a demanding and controversial topic, but part of the problem students have always faced is an imperative to follow the conventions of their academic discipline without understanding them and sometimes without even knowing what they are.

I had myself experienced the valuable effects of regenring in my parody of Plato's Symposium. When I came to plan a week's work on new academic literacies for my postgraduate part-time online students, I thought that I could use the idea of changing genre to encourage the students to engage with a text.

\section{Example: the Use of Parody in an Online Programme}

Students on a Master's programme in Digital Education were asked to consider resistance to new technology through parodying or regenring Socrates' reaction to writing in The Phaedrus. The students learned not only about technology acceptance (or lack of it) but also about Plato's work, about using multimodal techniques for representation, and about representation itself. And it generated a great deal of laughter and sense of community.

The context was the initial core course of the programme: An Introduction to Digital Environments for Learning. Week 10 was devoted to consideration of New Academic Literacies. Students had already been exposed to several debates about digital education along with critiques of different forms of environment and engagement.

Figure 3 shows the instructions for a week long activity. Students could engage as much or as little as they wanted; the activity was not assessed for credit, though they were still expected to maintain a blog which would be assessed. There was in addition a compulsory reading - Fitzpatrick, K. (2011). The Digital Future of Authorship: Rethinking Originality. Culture Machine, 12 . It was hoped that students would connect their reading to their efforts with the activity, and indeed several did this explicitly. Fitzpatrick particularly stresses that commenting, linking and versioning...

produce texts that are no longer discrete or static, but that live and develop as part of a network of other such texts, among which ideas flow.

(Fitzpatrick 2011:9)

...which was the very process being encouraged by the activity. 


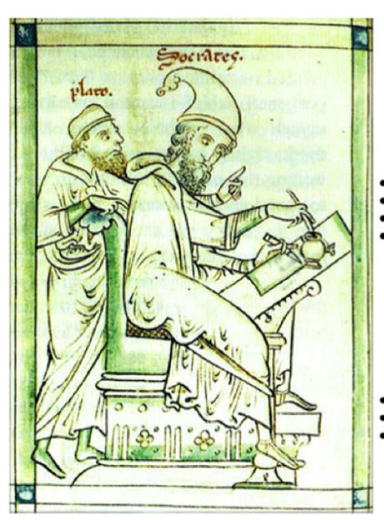

Fig. 3 Instructions for a parodying/regenring activity. (Illustration from Wikimedia Commons)

The text selected - from Plato's Phaedrus - is not an easy read, though one student, Gemma, greatly helped her peers by presenting it in cartoon form (see Fig. 4 for an extract). While this is not particularly parodic (and did not have to be), it is an excellent summary. The last frame incorporates Socrates' key point about the 'living word' (a phrase also used by Bakhtin) as well the main message of the week that digital texts are 'to be continued'. Thanks to Gemma Henderson for permission to reproduce this extract.

Students responded extremely well to this activity and shared their experiments in a discussion forum. As part-time mature mid-career professionals interested in digital environments, they brought a great many resources in terms of genre and media use. There were parodies based on Twitter, which made interesting points about dialogic potential and limitations of particular media, including Twitter; there were videos that brought together words, pictures and music and there was sharing of expertise in the remixing of video. There were poems and different kinds of image and other forms of reinterpretation. Laughter-inducing parody was involved in some of these, and also notably in a spoof newspaper article with several layers of parody. It parodied the activity by making references that would only be meaningful to other students on the course. It took the opportunity to parody a current political issue in the UK in 2015 - the upcoming general election. It used Socrates' arguments about writing to account for politicians being reluctant to publish manifestos because they claimed it would damage their ability to engage in public debate. This was truly double-voiced.

Students commented enthusiastically on each other's work, and some were inspired to adapt others' ideas. Several said that they had been particularly stimulated by the task and felt this was their most engaged on the course. However, the feedback was not all positive. Students were asked what they thought the purpose of the exercise was. While some made the connections with the week's core reading, other students felt that there was a greater emphasis on tools than on content and were concerned about the potential need for technical guidance to complete the task. The conversations helped identify 


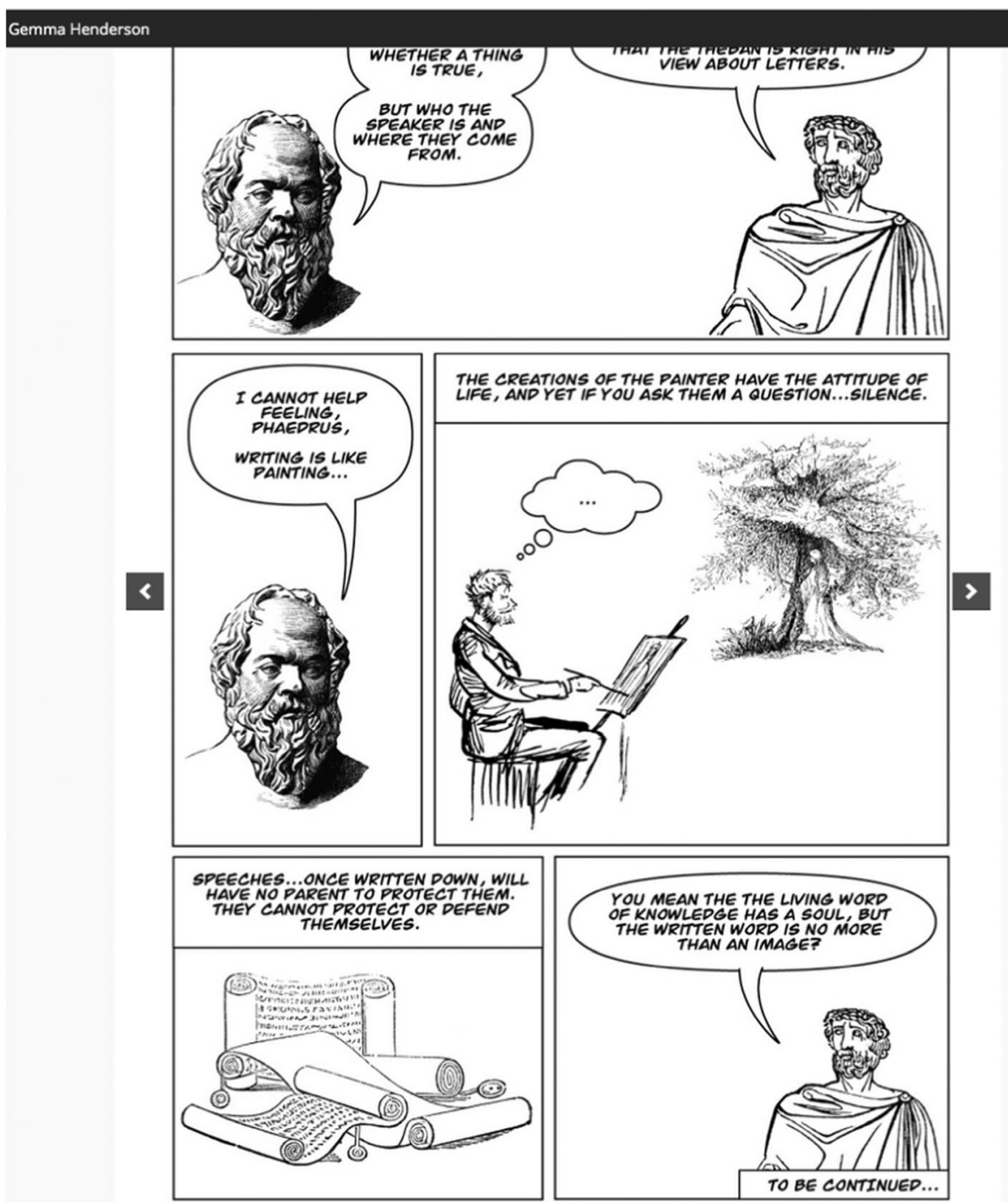

Fig. 4 Gemma's translation of the dialogue into a cartoon strip. ClipArt ETC, Educational Technology Clearinghouse, Florida Center for Instructional Technology, College of Education, University of South Florida.

future modifications to the course but also gave provided the tutor with an opportunity to clarify intentions and underline the main messages about new academic literacies.

Activities that engage students in experimenting with discourses in different genres will highlight how those genres work. For example, asking students to write a fake news article such as the one produced by the Yes Men for the fake Washington Post could alert them to the techniques used by the perpetrators. Of course, it could alternatively result in 'training' additional fake news writers with intentions that are not about parody! Any conclusions drawn from these examples may need careful consideration and attention to context. 


\section{Lies, Bullshit, Fake News, Parody, Laughter... and Brexit}

To return to the subjects of this special issue, it is clear that parody has some - possibly tenuous - associations with all three of the problem areas identified.

Lies: I have pointed out that parody is likely to involve fabrication. This might be seen as a euphemism for lying; however, in this paper I have been using the understanding of lying as having 'the express intention of deceiving or misleading the receiver' (Mackenzie and Bhatt 2018). Fabrication might have other purposes, as in storytelling, analogy, jokes, and acting (to name but a few). I suggest that parody and satire actually fail when they deceive and for this reason, they should be distinguished from lies. Parody is not lies: it may use fabrication to expose lies and liars.

Bullshit: Similarly, parody and bullshit may seem to share some attributes mainly that they involve fabrication and exaggeration with a kernel of actual or potential truth. Again, bullshit involves an intention to deceive but even more importantly, a lack of care for what the truth might be (Frankfurt 2005; Ball 2017). Some forms of parody may share this lack of care; the examples offered here so far certainly do not, so lack of care for 'truth' is not a defining feature of parody, as it is for bullshit. Parody is not bullshit: it may use fabrication, exaggeration and distortion to expose bullshit and bullshitters.

Fake news: Fake news has proved more difficult to separate out, because of parody's appearance in typologies of fake news. Fake news has itself become a bloated construct, not least because of the recent indiscriminate use of the term by some bullshitters to cover their own 'unflattering coverage' (Wright 2019, this issue). A news parody is perhaps by definition 'fake' news - so in this sense we cannot fully dissociate the two. However, parody's purpose is not to pass itself off as real news. Parody also does not have to be unflattering, even though it is quite likely to be: it is more concerned with bringing certain people and practices to our attention. Fake news may use parody; parody in turn may expose the underlying mechanisms of fake news, which is why we should be educating ourselves about parody.

What is distinctive about parody over the three themes of our special issue is the presence of humour. Parody in its regenerative form is strongly associated with laughter. Lies, bullshit and fake news are not particularly associated with laughter. But laughter can be directed at them: laughing at the perpetrators through satirical attack, or laughing with them as we parody the conditions in which we find them. The example at the end of this section is a collection of some uses of laughter-generating parody in response to a particular set of lies, bullshit and fake news.

For Bakhtin, the importance of laughter as a form of resistance to authoritarianism is clear in extracts 'From Notes Made in 1970-71', where he particularly praises joyful festive laughter, over the more negative kind. He even goes so far as to say 'Everything that is truly great must include an element of laughter.' (Bakhtin 1986:135). Creative writer Nate White would agree. In response to a question on US question and answer website, Quora, he castigated a president's inability to say anything remotely funny.

I mean it quite literally: not once, not ever. And that fact is particularly disturbing to the British sensibility - for us, to lack humour is almost inhuman. (White 2019) 
Not everyone would agree with Nate White's judgement - see for example Reilly (2018) who makes the opposite claims about this person's humour. However, the already over-cited president is not really the point of referencing White here; the significance of laughter to many people is the point. The Quora answer quickly went viral; along with some 'bare negation' in the form of insults, it contained examples of elegant writing which readers admired. The 'British sensibility' that White refers to has been sorely tried in recent times, and it sometimes appears that there is not much to laugh at, especially in any generative and renewing way. So it seems appropriate to use Brexit as the theme of our final example in this exploration of parody.

\section{Example: the Use of Parody in Relation to Brexit}

The art of political parody merits more study in its own right than it gets.

(Edwards 2019:216)

At the time of writing, people in Britain are undergoing a political crisis and social division. The deep split of the country apparently into two halves - remainers and leavers - belies the complexities of the overall situation. Lies, bullshit and fake news are widely reported by both sides of the division. Often the reports take the form of shrill name-calling - elitists, the establishment and 'remoaners' versus racists, the elderly and the stupid. This bare negation may provide a release for anger, but it certainly does not generate joyful laughter, nor does it further any form of dialogue that might lead to understanding of each other's position.

However, the Brexit process has still been on the receiving end of much satire and parody. Some of that is itself a release from anger or fear: for example, creating a cover with a London bus full of allusions to Britain 'going bonkers' over Brexit for Time magazine proved to be an antidote to fear of Brexit for its artist, Cold War Steve, according to an interview in The Observer newspaper (Sherwood 2019). His cartoon is very sharp and funny, while still drawing attention to the reasons for his fears. Buses are popular memes for postdigital parody of Brexit. The 'Bollocks to Brexit' bus parodied the Vote Leave Campaign bus with its controversial (and bullshit) claim that $£ 350$ million would be available for the National Health Service. The parodying bus was equally controversial, not least because the Speaker of the House of Commons, John Bercow, was seen driving a car (his wife's) bearing the same slogan.

There have been parodies from the leavers side too, though not many, and this has been attributed to the 'echo chamber' effect and the fact that most comedians are left wing (Weaver and Lockyer 2018). The echo chamber effect brings a danger of underestimating the strengths of the other side's feelings: remainers are simply not exposed to them, beyond the taunts and name-calling. Some, however, have actively sought out the views of the leavers and will join in discussions on their websites.

An online search for pro-Brexit parody highlights a viral tale of a leavers' spoof that backfired, because it was hijacked by remainers. A Facebook page, Britain Bites Back, attempted to launch a second referendum poll, assuming their readers would help make the case for the pointlessness of the 'Revoke Article 50' petition. Unfortunately, their poll showed a massive support for the remain position, even when they tried to run it again 
(see Waters 2019, and many other sources). It appears that many commentators did not realize that the poll was a parody; nor indeed did some of the subscribers to the site.

Much of the parody about Brexit is directed at the attempts of Prime Minister Theresa May to get a Brexit deal through Parliament, and this is arguably amusing for both leavers and remainers. One popular example draws on viewers' knowledge of both Gollum as voiced by Andy Serkis in the film Lord of the Rings and the Queen song Bohemian Rhapsody - and the comments indicate that even leavers found it hilarious. https://www.youtube.com/watch?v=poH77DGFmRo

As Owen Dudley Edwards observes in his essay on 'The Blyton Brexit Parodies' in relation to political parody: 'Some of its finest expressions mingle several art forms...' (Edwards 2019: 216). There are clearly ample opportunities to do this nowadays. However, in order to be good examples of parody they need to be true to all the voices represented in the double-voiced discourse. Edwards' essay on Bruno Vincent's (2016, 2017) parodies of Enid Blyton's work and Brexit found the author's knowledge of Blyton somewhat wanting. Edwards laments the lack of recognition of Blyton's own humour; however, he concedes that Vincent has been successful in using the Famous Five books to expose the risk of totalitarianism following Brexit. Edwards concludes:

However seriously intended, Mr Vincent does not represent Blyton comedy. But as her tragedy representative he gives us something to think about. So did she. (Edwards 2019: 227)

Edwards' essay would seem to reinforce the case for education about parody (as well as children's literature), particularly to allow for interpretation of complex issues such as Brexit and to help improve the quality of parody itself. What is important is to recognize the resonances that give us something to think about - to understand why people are laughing. This suggests that the use of parody and other forms of humour should be researched to support its creative application and educational potential. There has been little research on comedy relating to Brexit (Weaver and Lockyer 2018). Weaver himself has undertaken a study exploring irony and satire in relation to Brexit, through a rhetorical discourse analysis approach (Weaver 2019). He finds an irony in pro-Brexit political discourse constructed around taboo and transgression that is hard for political adversaries to critique. He describes this as a 'trickster' tactic; where tricksters are 'brokers of change or ambiguity', and maintains that political satire is better placed to expose and analyse the ironies of the discourse used by tricksters. Weaver uses the satire of the US TV programme From Last Week Tonight with John Oliver to show how Oliver achieves this with Brexit leading figures, Michael Gove and Nigel Farage.

The trickster, jester and fool are recognizable figures from mythology, folklore and indeed carnival, who help others to challenge and subvert authority. They are sometimes invoked as useful for innovative teaching, as in the work of Macleod and Ross (2011) who see their value for online tutoring. Weaver's example of trickster tactics in relation to Brexit indicate a potential for transgression that might be seen as less progressive to many readers and writers of this special issue.

A feature in the London-based Arab news and political magazine Majalla (Haworth 2019) also picks up the jester/trickster theme, with specific reference to the work of Bakhtin on carnival culture as it has applied to Brexit. The humour and tone of the article reinforce Weaver's point that we may need political commentary based on satire 
to expose the ironies of the Brexit position: Haworth's is not an academic article but it is certainly worthy of our attention, especially at a time of leadership change in the UK. At the time the article was written, a leader in waiting was showing himself to be a liar, a bullshitter and a producer of fake news in his own newspaper column - but also an excellent satirist in his own right.

Johnson did not invent Euroscepticism but he took it to new levels. A brilliant caricaturist, he made his name by mocking, lampooning and ridiculing the EU...

Haworth goes on to put Boris Johnson in the jester role, but notice that this is jester for the elite, not for the people:

Boris is the Lord of Misrule, the Great Disrupter. In his role as Will of the People, he is the subterranean voice of the populace groaning under the yoke of Brussels... The elite needed a jester and every conference season he gave them one.

See Haworth 2019 - https://eng.majalla.com/node/71176/brexit-a-very-british-carnival

Thus humour, recognition of double-voiced discourse and appropriate responses to tricksters are all significant issues for the Brexit debate. There is scope for much scholarship and research and the blending of that research with satirical and humorous commentary.

The above conclusion about tricksters is not only relevant to our Brexit example. There are many such tricksters. Elizaveta Gaufman draws attention to another one, again with explicit reference to Bakhtin's notion of carnival and laughter:

Carnival culture with its opposition to the official buttoned-up discourse is supposed to be polar opposite, distinguished by anti-ideology and anti-authority, in other words, anti-establishment... (Gaufman 2018: 410)

Gaufman then goes on to elaborate how Bakhtin's concept of carnival culture has been directly applicable to a successful presidential campaign.

The problem is that the disruptive features of carnival are meant to be temporary. When they are long term, and tricksters become world leaders in several different countries, then carnival is no longer a laughing matter.

\section{Conclusion}

This is not a paper about literature, though that was the original context for Bakhtin's ideas. Nor is it about Socratic dialogues, though Bakhtin did see them as the precursor to the modern novel (Bakhtin 1981). However, these are places where parody has been shown to expose different ways of engaging with 'truth' and the effects that the same words can have in different mouths.

What the paper has attempted to do is expose the pervasiveness and potential effects of parody - positive, benign or malign. It suggests paying attention to parody, so that it doesn't simply become a lazy association with fake news, even though parody may play a part in the production of fake news. It has considered the mechanisms of parody 
through double-voiced discourse that can simultaneously make an author's point and refract the views of another author with different intentions and values. It has suggested an approach to education that has proved relevant and simulating to students, in part because of the laughter involved, and at the same time teaches them about both voices in double-voiced discourse. Finally, it has looked at the interactions of parody with lies, bullshit and fake news as might be seen in contemporary political and social contexts. It raises the uncomfortable prospect that anti-establishment humour, laughter and parody have been appropriated by rich and privileged tricksters and jesters who now have too much power.

It might be asked why all this is considered necessary for the postdigital era. Like Dentith (2000) with respect to postmodernism, I would be reluctant to claim any special role for parody for the postdigital, but I do think that we pay parody insufficient attention and we allow it just to become part of the background noise (admittedly, some of it deserves to remain there). We should pay attention primarily because there are urgent matters in need of critique and parody can help to expose them. If there is parody going on, we all need to 'get' it; otherwise it becomes elitist and divisive. We should pay attention to techniques that will enable us to 'hear' the different voices using the same words and to understand the resonances of both the parodied and parodist. We should pay attention to parody in our quest for postdigital media literacy, not only for young people but for us all. And we should be able to benefit from the laughter that accompanies parody and encourages sharing and dialogue.

Parody accompanied by laughter is one of our specifically human practices, even if we use technology to support it. While humour could be built into artificial intelligence, we are more likely to laugh at robots than with them. Parody is in any case not work that we should be delegating to automation but is one way of maintaining our critical and social faculties in an age when there is too much going on. It is not necessarily an antidote to lies, bullshit and fake news, though it may be. We do not know where parody of our contemporary customs, practices and values will take us; but parody will definitely be present. We need to be able to use it to promote beneficial consequences such as increased literacy and to resist malign ones such as fake news and tricksters. But we should always remain aware that some of the consequences of parody may be beyond our control and understanding.

Open Access This article is distributed under the terms of the Creative Commons Attribution 4.0 International License (http://creativecommons.org/licenses/by/4.0/), which permits unrestricted use, distribution, and reproduction in any medium, provided you give appropriate credit to the original author(s) and the source, provide a link to the Creative Commons license, and indicate if changes were made.

\section{References}

Bakhtin, M. M. (1981). Discourse in the novel (C. Emerson, \& M. Holquist, Trans.). In M. Holquist (Ed.), The dialogic imagination by M. M. Bakhtin. Austin: University of Texas Press.

Bakhtin, M. M. (1984a). Problems of Dostoevsky's poetics (C. Emerson, Trans.). Minneapolis: University of Minnesota Press.

Bakhtin, M. M. (1984b). Rabelais and his world (H. Iswolksy, Trans.). Bloomington: Indiana University Press. Bakhtin, M. M. (1986). Speech genres and other late essays (V. McGhee, Trans.). Austin: University of Texas Press. Ball, J. (2017). Post-truth: How bullshit conquered the world. London: Biteback Publishing. 
Bartholomae, D. (1985). Inventing the university. In M. Rose (Ed.), When a writer can't write. New York and London: Guilford Press.

Baxter, J. (2011). Survival or success? A critical exploration of the use of 'double-voiced discourse' by women business leaders in the UK. Discourse \& Communication, 5(3), 231-245. https://doi.org/10.1177 $/ 1750481311405590$.

Brewer, P., Young, D. G., \& Morreale, M. (2013). The impact of real news about "fake news": intertextual processes and political satire. International Journal of Public Opinion Research, 25(3), 323343. https://doi.org/10.1093/ijpor/edt015.

Daniel, M. (2018). I write fake news. I'm not part of the problem. TEDxYouth@RVA: TEDx Talks.

Dentith, S. (2000). Parody. London: Routledge.

Edwards, O. D. (2019). The Blyton Brexit parodies. Scottish Affairs, 28(2), 216-227.

English, F. (2011). Student writing and genre. London: Bloomsbury.

Fitzpatrick, K. (2011). The digital future of authorship: rethinking originality. Culture Machine, 12.

Frankfurt, H. (2005). On bullshit. Princeton: Princeton University Press.

Freeden, M. (2018). Loose talk costs... nothing. Journal of Political Ideologies, 23(1), 1-9. https://doi. org/10.1080/13569317.2018.1413825.

Gaufman, E. (2018). The Trump carnival: popular appeal in the age of misinformation. International Relations, 32(4), 410-429. https://doi.org/10.1177/0047117818773130.

Glaser, A. (2019). The fake Washington post wasn't fake news. Slate, 17 January. https://slate. com/technology/2019/01/fake-washington-post-not-fake-news-y.es-men-parody.html. Accessed 1 July 2019.

Greenman, B. (2019). Is satire possible in the age of Trump? The New York Times, 28 January. https://www. nytimes.com/2019/03/08/books/review/mark-doten-trump-sky-alpha.html. Accessed 1 July 2019.

Haworth, B. (2019). Brexit: A very British carnival. Majalla, 17 May. https://eng.majalla.com/node/71176 /brexit-a-very-british-carnival. Accessed 20 June 2019.

Mackenzie, A., \& Bhatt, I. (2018). Lies, bullshit and fake news: Some epistemological concerns. Postdigital Science and Education. https://doi.org/10.1007/s42438-018-0025-4.

Macleod, H., \& Ross, J. (2011). Structure, authority and other Noncepts. In R. Land \& S. Bayne (Eds.), Digital difference: Perspectives on online learning. Rotterdam: Sense Publishers. https://doi.org/10.1007 /9789460915802_003.

Plato. (2009). Symposium. In D. Widger (Ed.), The project Gutenberg works of Plato (pp. 8391-8548).

Reilly, D. (2018). Sorry folks, but Donald Trump is funny. Intentionally funny. The Spectator, 20 March. https://spectator.us/sorry-folks-but-donald-trump-is-funny-intentionally-funny/. Accessed 1 July 2019.

Renfrew, A. (2015). Mikhail Bakhtin. Abingdon: Routledge.

Rose, M. A. (1991). Post-modern Pastiche. British Journal of Aesthetics, 31(1), 16-38.

Sherwood, H. (2019). Cold war Steve: satire is my antidote to a scary world. The Observer (16 June 2019).

Sinclair, C. (2020). Laugh with us, not at us: Parody and networked learning. In M. De Laat, N. B. Dohn, P. Jandrić, \& T. Ryberg (Eds.), Mobility, Data and Learner Agency in Networked Learning. London: Springer. (Forthcoming).

Tandoc, E. C., Lim, Z. W., \& Ling, R. (2018). Defining “fake news". Digital Journalism, 6(2), 137153. https://doi.org/10.1080/21670811.2017.1360143.

Vincent, B. (2016). Five on Brexit Island. London: Quercus Publishing.

Vincent, B. (2017). Five escape from Brexit Island. London: Quercus Publishing.

Vygotsky, L. S. (1978). Mind in society. Cambridge: Harvard University Press.

Waters, L. (2019). Parody Brexiteer Facebook page called Britain Bites Back launched second referendum poll - it hilariously backfires twice. Independent, 28 March. https://www.indy100.com/article/brexitleave-britain-bites-back-facebook-comments-funny-revoke-article-50-partition-8843211. Accessed 1 July 2019.

Weaver, S. (2019). Brexit tricksters and the reconstruction of taboo. Populism, irony and satire in postreferendum Britain. Comedy Studies. https://doi.org/10.1080/2040610X.2019.1623495.

Weaver, S., \& Lockyer, S. (2018). Is Brexit funny? The cultural significance of comedy about Brexit. https://blogs.1se.ac.uk/brexit/2018/06/26/is-brexit-funny-the-cultural-significance-of-comedy-aboutbrexit-echo-chamber/\#comments. Accessed 20 June 2019.

White, N. (2019). Why do some British people not like Trump? Mountain View: Quora.

Wright, J. (2019). 'Many people are saying...': Applying the lessons of Naïve skepticism to the fight against fake news and other 'Total bullshit'. Postdigital Science and Education. https://doi.org/10.1007/s42438019-00051-0. 